Turkish Online Journal of Qualitative Inquiry (TOJQI)

Volume 12, Issue 2, April 2021: 405-437

DOI: $10.17569 /$ tojqi.852044

Review Article

\title{
Educational Journey of Refugee Students: Suggestions for Practitioners ${ }^{1}$
}

\author{
Dilara Özel², Hilal Altunay-Yılmaz ${ }^{3}$
}

\begin{abstract}
There are 79.5 million people, including children, left their home countries forcibly. Besides, the duration of exile for people who forcibly displaced their countries becomes 17 years. During the time refugees stay in the host countries, they try to learn the host country's culture, traditions, and values to adapt and survive. Schools are the key components to develop cultural competency. Within this study, it is aimed to review articles that include examples of good practice for school counselors and teachers working with refugee students. In this review, metaanalysis is utilized to examine the qualitative studies about the educational process of refugee students. Forty-one studies included in this meta-analysis. These 41 studies divided into four main themes; refugees' adaptation, school experiences, policies, and refugee health. Best practices for teachers and school counselors who are working at refugee- receiving schools were presented.
\end{abstract}

Keywords: Refugees, refugee education, psychosocial approach, practitioners

\footnotetext{
${ }^{1}$ The initial findings of the study were presented at the 9th International Congress on Psychological Counseling and Guidance" held in Marmara University, İstanbul (Turkey) on 15-17th November 2019. The ethical committee permission is not required in this research since this is a review study.

${ }^{2}$ Research Assistant, Middle East Technical University, Faculty of Education, Department of Educational Sciences, ozeldilara@gmail.com,https://orcid.org/0000-0003-1250-599X

${ }^{3}$ Research Assistant, Middle East Technical University, Faculty of Education, Department of Educational

Sciences, hilal.altny@gmail.com, https://orcid.org/0000-0002-7410-2232
}

Received: 01.01.2021, Accepted: 23.03.2021 


\section{Eğitim Sürecinde Mülteci Öğrenciler: Uzmanlar için Öneriler}

\section{Öz}

Çocuklar dahil olmak üzere zorla yerinden edilen 79,5 milyon kişi bulunmaktadır. Zorla yerinden edilen kişilerin ev sahibi ülkede kalma süresi 17 yılı bulmuştur. Ev sahibi ülkede kaldıkları süre boyunca mülteciler uyum sağlamak ve hayatlarını devam ettirebilmek için ev sahibi ülkenin kültürünü, geleneklerini ve değerlerini öğrenmeye çalışmaktadırlar. Okullar kültürel yeterliliği geliştirmede kilit bir rol üstlenmektedirler. Bu çalışma ile birlikte mülteci öğrenciler ile çalışan okul psikolojik danışman ve öğretmenler için iyi uygulama örneklerinin derlenmesi amaçlanmıştır. Bu derleme çalışmasında mülteci öğrencilerin eğitim süreçleri hakkındaki nitel çalışmaların incelenmesinde meta-analiz yöntemi kullanılmıştır. Bu metaanaliz çalışmasına 41 çalışma dahil edilmiştir. Bu 41 çalışma, dört tema altında incelenmiştir; mülteci uyumu, okul deneyimleri, politikalar ve mülteci sağlığı. Mülteci alan okullarda çalışan okul psikolojik danışmanları ve öğretmenler için iyi uygulama örnekleri sunulmuştur.

Anahtar Sözcükler: Mülteciler, mülteci eğitimi, psikososyal yaklaşım, uygulayıcılar 


\section{Introduction}

United Nations signed the Geneva Convention in 1951 and 1967 Protocol, which provides international rights to refugees as a result of historical circumstances. United Nations used the definition of the 1951 Geneva Convention relating to the status of refugees in its 1967 Protocol which is;

"Refugee is a person who, owing to well-founded fear of being persecuted for reasons of race, religion, nationality, membership in a particular social group or political opinion, is outside the country of his nationality and is unable or, owing to such fear, is unwilling to avail himself of the protection of that country; or who not having a nationality and being outside the country of his former habitual residence, is unable or, owing to such fear, is unwilling to return to it." (Convention and Protocol, 1951/ 1996).

Around the world, approximately 79.5 million people left their home countries forcibly, and 26 million of them, which includes around 13 million children who obtained refugee status (UNHRC, 2020). People gain some basic rights with the refugee status such as rights for education and health in the host country. The world is dealing with the refugee crisis. After the Cold War, irregular conflicts and wars have changed their nature. There are two main characteristics of these conflicts and their consequences (Dryden- Peterson, 2014). First, contemporary conflicts have more disastrous consequences, particularly for children (Save the Children, 2013). As a result of those conflicts, children are more likely to become refugees, and they need to learn the host country's culture, language, plus customs and practices while developing their identity. Children need their parents to meet their basic needs, both psychologically and physically. Thus, parents' mainly primary caregivers' emotional reactions towards war and conflict situations affect children's development (Barbara, 2006).

Parents as primary caregivers are affected with the conflict situations more than expected, since contemporary conflicts have a longer duration than expected. Even though the refugees desire to return to their home countries, the average period of displacement for refugees is 17 years (International Displacement Monitoring Center, 2014). Many conflicts that recently ended lasted for decades, such as in Afghanistan (33 years), the Democratic Republic of the Congo 
(19 years), and Somalia (23 years) (Center for Systemic Peace, 2017). Therefore, even the refugees desire to go back to their home countries; it takes a while to develop the conditions. Throughout the time refugees stay in the host countries, they attempt to learn the host country's culture, traditions, and values to adapt and survive. Considering schools are the places, not just places to teach, write, and read but also to raise citizens who can maintain the culture of society, they are the fundamental components to promote cultural competency. In this review, metasynthesis analysis is conducted to examine the qualitative studies about the educational process of refugee students. Hence, it is aimed to assemble best practices to guide the teachers and the school counselors that work at refugee- receiving schools.

\section{Literature Review}

Conflicts and traumatic experiences influence everyone unquestionably. On the other hand, children are the ones who are affected most from all traumatic experiences. The principal reason is that children need their primary caregivers for their both developmental and emotional needs (Barbara, 2006). Furthermore, war and conflict situations harm children's social life more than adults. Most of the children may have to immigrate to a new country without getting any education in their country of origin. Those children who began their life in refugee camps cannot reach their education right most of the time (Barbara, 2006). Consequently, it is hard for children to adapt to a new school, home, and country after staying at refugee camps for years and without getting psychological help. Therefore, school has a vital role in terms of this adaptation process. Schools help refugee children to introduce the host country's culture, build friendship with local peers and learn the host country's language.

While schools have the primary importance for refugee children during the adaptation process, attending a school in a different country brings some adaptation issues as well. Every component of the school comes with its own culture and history in the classroom. Students' families and siblings may form the communication that students create with their peers and teachers. On the other hand, refugee students' experiences might be different than local students. Refugee students' migration paths, reasons for settling down to a specific city, and their experiences during the settlement are unique and have an impact on the classroom environment (Dryden- Peterson, 2014). Therefore, uniqueness of children should be considered in every step of the adaptation process. 
Schools may become the most influential agent for the adaptation process of refugee children since they are the key components to develop cultural competency (Gardner, 1995). They are a crucial tool for refugee students to communicate and adapt to the host country (Saldana, 2013). Schools support refugee students to understand the host country, gain social support, develop trusting relationships, and feel belonging to the host country. Schools are the reflections of society by teaching the customs and traditions of society. Therefore, they do not just show how to read and write, but also, they help to maintain the culture of society. Hence, schools have a notable role for refugee students in their acculturation and adaptation process to the host country (Peterson, Meehan, Ali \& Durrant, 2017). This important role of the schools should demonstrate itself in the context of Turkey as well.

Since the refugees in Turkey started to increase day by day, the government in Turkey started to take measures for the adaptation process. However, there are historical restrictions for Turkey to implement some changes. Turkey signed the Geneva Convention in 1951 with restrictions about 'time' and 'geographical limitation.' In 1967, Turkey removed the 'time' restriction but preserved the 'geographical limitation.' This restriction indicates that Turkey can give the 'refugee' status only for the people who come from European countries to Turkey. Thus, people came from Syria considered as 'asylum- seekers' and could not benefit from the rights of 'refugee' status.

Turkey started to receive people from Syria in 2011. In the first place, Turkey conducted an 'open door' policy and accepted all the people who came from Syria with their self- declaration. Since the war in Syria was considered as a temporary situation, temporary precautions were carried out by the governmental institutions in Turkey. Turkey started the adaptation process for the first time with law number 6458 that was introduced in 2013. The Department of Harmonization and Communications was founded to start the adaptation process of people under temporary protection and work with the universities, NGOs, and governmental institutions (Law on Foreigners and International Protection, 2013).

Language becomes the hierarching theme of all the problems that refugee children encounter during their education in Turkey (Özel, 2018; Sarmini, Topcu \& Scharbrodt, 2020). Since most of the teachers cannot speak Arabic with their Syrian students, They are asking other students 
or inviting adults who can speak Arabic for the translation (Sarmini et al., 2020). Özel (2018) revealed in their interviews with school counselors that the school counselors are using others for the translation process which is not ethical for the counseling services. Thus, it is stated that school counselors cannot discuss the private matters such as students' trauma and family issues since they cannot ensure confidentiality.

Furthermore, trauma is a high prevalent issue among Syrian refugees in Turkey (Acartürk et al., 2020). In their study, they have collected data among Syrian refugees by using Hopkins Symptoms Checklist to measure depression, anxiety and posttraumatic stress disorder (PTSD). As a result, they found that the prevalence of depression, anxiety and PTSD among the refugees are $36.1 \%, 34.7 \%$ and $19.6 \%$ respectively. As it is indicated with these numbers, the prevalence of mental disorders is very high among the refugees. Furthermore, they have found that comorbidity is a vital issue in addition to the mental disorders. They have stated some comorbid issues such as being a female, having economical difficulties, lack of social support and safety. Family violence and child labor issues can be added to this comorbidity list as well (Sahin, Dagli, Acartürk \& Sahin Dagli, 2020).

The literature is rife with studies about the role of education during psychosocial development of refugee students (Kaya \& Kıraç, 2016; Mercan Uzun \& Bütün, 2016; Özel, 2018; Özer, Komşuoğlu \& Ateşok, 2016; Sakız, 2016). Although there are many need analysis conducted with teachers and school counselors who are working at refugee- receiving schools, it is noticed that the problems inside the refugee- receiving school still continue (Balkar, Şahin \& Işıklı Babahan, 2016; Doğutaş, 2014; Dorman, 2014; Ereş, 2016; İstanbul Bilgi University Children's Studies Unit, 2015; Şeker \& Sirkeci, 2015). Yet, there is an urgent need for studies that focus on the problems faced by refugees, which may nurture teachers and school counselors in dealing with issues. In this study, studies and good practices for teachers and school counselors who are working with refugee students are compiled. Consequently, it is aimed to guide teachers and school counselors who are working at refugee- receiving schools.

\section{Methodology}

In this study, a meta-synthesis procedure is used to evaluate the studies about refugees' educational process and integrate the results of qualitative studies systematically (Lachal, 
Revah- Levy, Orri \& Moro, 2017). The qualitative meta-synthesis analysis is a crucial tool to understand participants' experiences, the meaning that they ascribe to those experiences, and their viewpoints. This method enables us to evaluate qualitative research in a comprehensive and detailed way. Therefore, it may be considered as the most useful tool to determine the points that need to be developed and recommend further applications (Tong, Flemming, McInnes, Oliver \& Craig, 2012). Meta-synthesis is considered as the best method for this study due to the reasons indicated above.

Electronic search is conducted in the following databases, including both English and Turkish language: Academic Search Complete, PsychINFO, Education Source, Social Sciences Citation Index, ERIC, ScienceDirect. The key search terms as "refugee," "education of refugee," "psychosocial," and "application" are used. The last search is conducted on 21.06.2019 by using the key search terms indicated above. There are 66 studies found by using "refugee" \& "education of refugee" \& "psychosocial" terms and 83 pieces of research found by using "refugee" \& "education of refugee" \& "application" terms before assigned the criteria. The following criteria are included in this meta-synthesis;

Criteria 1: Since the impacts of war in Syria started to influence Turkey in 2011, studies conducted in 2011 and after 2011 are included in the present research.

Criteria 2: The studies included in this research are written in English and/ or Turkish language.

Criteria 3: The studies included in this research are published in peer-reviewed journals.

Criteria 4: The studies included in this research are in accordance with the aim of this research.

Obtained studies by searching at the databases stated above on the occasion of adopting the relevant key terms indicated above and applying the specified criteria are indicated in Table 1. 
Table 1

Number of obtained international articles after the stated criteria

\begin{tabular}{|c|c|c|}
\hline Key Terms & Database* & $\begin{array}{l}\text { The Number of Studies Obtained } \\
\text { after Determined Criteria }\end{array}$ \\
\hline \multirow{7}{*}{$\begin{array}{l}\text { Refugee and education of refugees } \\
\text { and psychosocial }\end{array}$} & Academic Search Complete & 12 \\
\hline & PsychINFO & 10 \\
\hline & Education Source & 9 \\
\hline & Social Sciences Citation Index & 4 \\
\hline & ERIC & 3 \\
\hline & ScienceDirect & 1 \\
\hline & Total & $25^{*}$ \\
\hline \multirow{7}{*}{$\begin{array}{l}\text { Refugee and } \\
\text { application }\end{array}$} & Academic Search Complete & 12 \\
\hline & PsychINFO & 4 \\
\hline & Education Source & 12 \\
\hline & Social Sciences Citation Index & 8 \\
\hline & ERIC & 7 \\
\hline & ScienceDirect & 1 \\
\hline & Total & $27 *$ \\
\hline
\end{tabular}

* As a result of the search, exact duplicates in the databases were excluded from the total numbers given.

After applying the stated criteria, it attained 52 studies. The elimination process is given in Figure 1 and 2. 


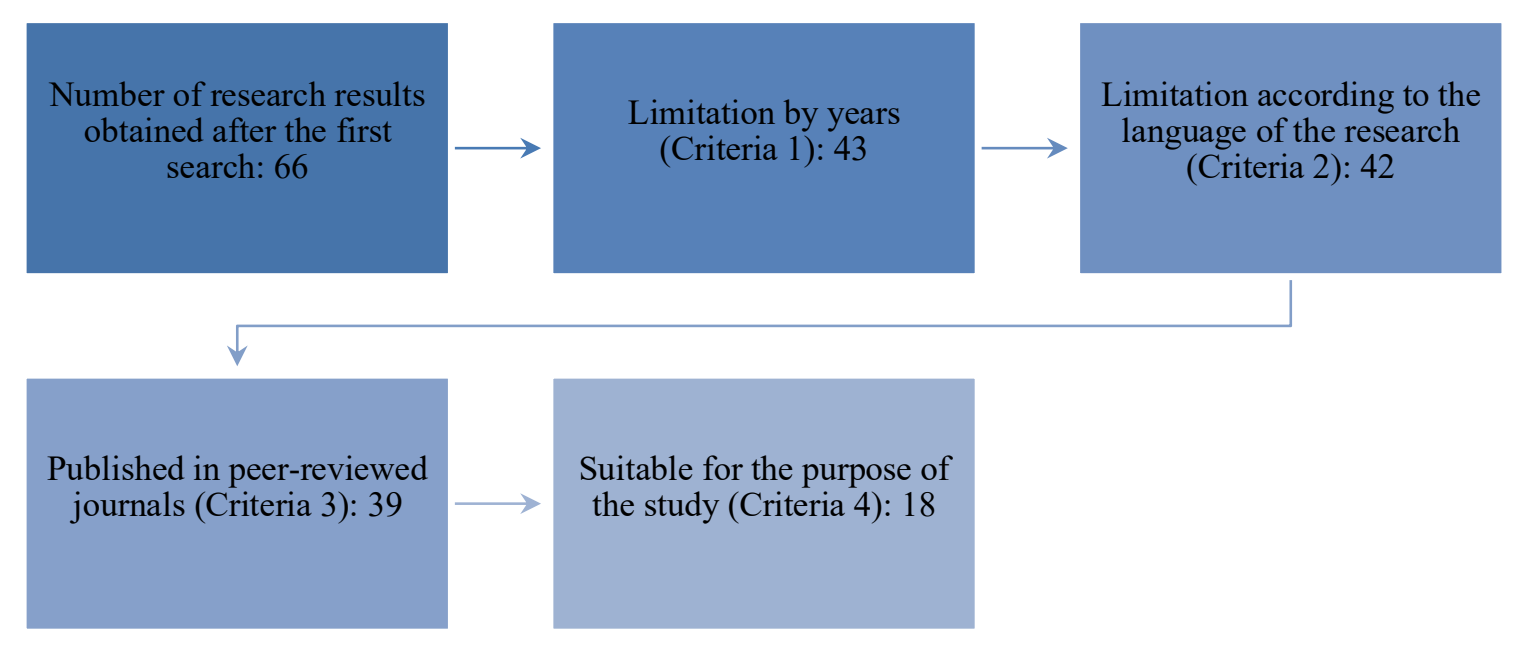

Figure 1. Including key terms of "refugee" \& "education of refugee" \& "psychosocial" into the present meta-synthesis

Sixty-six relevant studies found as a result of the first search by using the key terms about the refugee students' psychosocial adaptation during the educational process (see Figure 1). After that, 43 studies are obtained by restricting according to the relevant years (criteria 1). Fortytwo studies are acquired after restricting the language (criteria 2), 39 studies after including just peer-reviewed journals (criteria 3), and, ultimately, 18 studies after considering the aim of this study (criteria 4). As a result, the number of studies included in this meta-synthesis about the psychosocial adaptation of refugee students in the educational process is determined as 18 . 


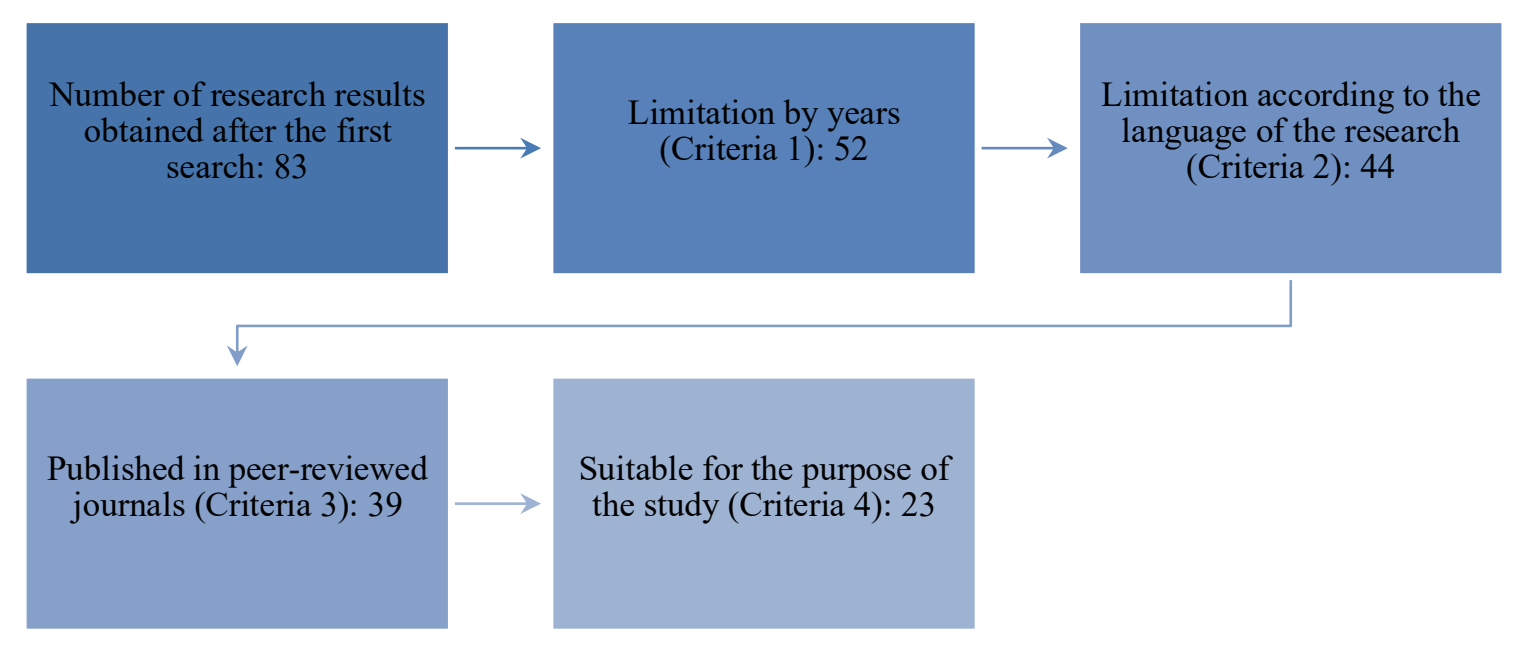

Figure 2. Including key terms of "refugee" \& "education of refugee" \& "adaptation" into the present meta-synthesis

Eighty-three relevant studies are found as a result of the first search by using the key terms about the refugee students' adaptation during the educational process (see Figure 2). After that, 52 studies are obtained by restricting according to the relevant years (criteria 1). It acquired 44 studies after restricting the language (criteria 2), 39 studies after including just peer-reviewed journals (criteria 3), and, ultimately, 23 studies after considering the aim of this study (criteria 4). As a result, the number of studies included in this meta-synthesis about the psychosocial adaptation of refugee students in the educational process is determined as 23 .

\section{Transferability of Research}

Triangulation procedure, which provides transferability and trustworthiness in qualitative research, includes multiple sources and/or multiple analysts for the analysis of the data to provide an in-depth understanding of the data. Triangulation offers the opportunity to handle the data from different perspectives and understand the data from different ways rather than reaching a consensus (Creswell, 1998). 
Meta-synthesis does not include a usual coding process of the data. It depends on the researchers' judgments, insights, basically their subjective interpretation of the selected qualitative studies. Collaborative working assists in improving the reflexivity of the research as well (Barry, Britten, Barber, Bradley \& Stevenson, 1999; Denzin \& Patton, 1999).

In this research, the analyst triangulation method was used to improve the trustworthiness of the study. Researchers carefully read all the selected studies and identify, organize, and compare these studies with the other ones. Two researchers grouped and categorized all the themes across the articles and matched each theme with other similar themes from different articles. The list of themes is described by two different researchers. At the end of the data analysis, researchers compared their list of themes and generated analytical themes, which includes researchers' insights and subjective judgments. Themes prepared by the different researchers and the researchers of this article resembled each other. Thus, consensus has been reached. This process helps researchers to go beyond descriptive synthesis and develop a more conceptual argument (Thomas \& Harden, 2008).

\section{Findings}

In this study, it is aimed to make a synthesis of good practices for teachers and school counselors who are working at refugee- receiving schools. Thereby, the purpose of this study is to pave the way for a successful and productive adaptation process inside the schools for both refugee and local people. There are 41 studies included in this meta-synthesis. In this section, the information about the studies included in this meta-synthesis is given. Examined studies about refugees' adaptation process divided into four main themes; refugees' adaptation, school experiences, policies, and refugee health. Table 2 contains general information about the included studies within each separate theme. 
Table 2

Characteristics of the selected articles about the refugee's psychosocial adaptation during the educational process

\begin{tabular}{|c|c|c|c|c|c|}
\hline Author(s) & Year & $\begin{array}{l}\text { Type of } \\
\text { Study }\end{array}$ & Participants & $\begin{array}{l}\text { Research } \\
\text { Design }\end{array}$ & $\begin{array}{l}\text { Topic of the } \\
\text { Study }\end{array}$ \\
\hline Brenner \& Kia-Keating & 2016 & Article & Review & Descriptive & Review \\
\hline $\begin{array}{l}\text { Busch, Bihler, } \\
\text { Lembcke, Buchmüller, } \\
\text { Diers \& Leyendecker }\end{array}$ & 2018 & Article & $\begin{array}{lr}28 & \text { preschool } \\
\text { teacher } & \text { and } 96 \\
\text { teachers } & \end{array}$ & Qualitative & Interview \\
\hline Crea & 2016 & Article & $\begin{array}{ll}122 & \text { refugee } \\
\text { students } & \end{array}$ & Quantitative & Interview \\
\hline $\begin{array}{l}\text { Çeri, Nasıroğlu, Ceri \& } \\
\text { Çetin }\end{array}$ & 2018 & Article & $\begin{array}{ll}117 & \text { refugee } \\
\text { children } & \end{array}$ & Qualitative & Review \\
\hline de Wal Pastoor & 2015 & Article & $\begin{array}{l}40 \text { young refugees, } \\
14 \text { teachers, } 8 \\
\text { school counselors } \\
\text { and } 3 \text { school } \\
\text { principals }\end{array}$ & Qualitative & Review \\
\hline $\begin{array}{l}\text { Fegert, Diehl, } \\
\text { Leyendecker, Hahlweg } \\
\text { \& Prayon-Blum }\end{array}$ & 2018 & Article & Review & Descriptive & Interview \\
\hline Hayes \& Endale & 2018 & Article & 18 young refugees & Qualitative & Review \\
\hline Horlings \& Hein & 2018 & Article & Review & Descriptive & Interview \\
\hline Kok, Lee \& Low & 2017 & Article & $\begin{array}{l}115 \text { adolescent } \\
\text { refugees }\end{array}$ & Mixed Research & Review \\
\hline Kovinthan & 2016 & Article & 1 teacher & Qualitative & Descriptive \\
\hline Mola Okoko & 2011 & Article & 2 school principles & Qualitative & Interview \\
\hline Nakeyar, Esses \& Reid & 2018 & Article & Review & Descriptive & Interview \\
\hline $\begin{array}{l}\text { Ndengeyingoma, } \\
\text { Montigny \& Miron }\end{array}$ & 2014 & Article & 12 young refugees & Qualitative & Review \\
\hline Özcan & 2019 & Article & 30 refugee students & Quantitative & Comparison \\
\hline Pastoor & 2017 & Article & $\begin{array}{l}40 \quad \text { refugee } \\
\text { students, } 25 \text { school } \\
\text { employees and } 40 \\
\text { social workers }\end{array}$ & Qualitative & Review \\
\hline Siah, Lee \& Goh & 2015 & Article & 89 refugee students & Qualitative & Review \\
\hline Stewart & 2012 & Article & 51 young refugees & Qualitative & Review \\
\hline
\end{tabular}




\begin{tabular}{|c|c|c|c|c|c|}
\hline Tanaka & 2013 & Article & $\begin{array}{l}175 \text { preschool } \\
\text { teachers }\end{array}$ & Quantitative & Interview \\
\hline Alpaydın & 2017 & Article & Review & Descriptive & Review \\
\hline $\begin{array}{l}\text { Betancourt, Yudron, } \\
\text { Wheaton, W., \& Smith- } \\
\text { Fawzi }\end{array}$ & 2012 & Article & $\begin{array}{l}153 \text { adolescent } \\
\text { refugees }\end{array}$ & Quantitative & Application \\
\hline Campion & 2018 & Article & Review & Descriptive & Review \\
\hline Çelik \& İçduygu & 2018 & Article & $\begin{array}{l}14 \text { Syrian family } \\
\text { and } 6 \text { teachers }\end{array}$ & Qualitative & Interview \\
\hline Dogutas & 2016 & Article & 14 refugee students & Quantitative & Application \\
\hline Dundar & 2019 & Article & $\begin{array}{l}50 \quad \text { physical } \\
\text { education teachers }\end{array}$ & Quantitative & Interview \\
\hline Fruja Amthor & 2017 & Article & 10 adult refugees & Qualitative & Interview \\
\hline Harris \& Marlowe & 2011 & Article & $\begin{array}{l}20 \text { students and } 10 \\
\text { teachers }\end{array}$ & Qualitative & Interview \\
\hline Hastings & 2012 & Article & 6 refugee students & Qualitative & Interview \\
\hline Keri \& Sleiman & 2017 & Article & 124 adult refugees & Qualitative & Interview \\
\hline Koyama & 2013 & Article & $\begin{array}{lr}15 & \text { school } \\
\text { principals, } & 25 \\
\text { recruitment } & \\
\text { manager, } 16 & \text { adult } \\
\text { refugees } & \end{array}$ & $\begin{array}{l}\text { Ethnographic/ } \\
\text { Qualitative }\end{array}$ & Interview \\
\hline Koyama & 2015 & Article & $\begin{array}{lr}15 & \text { school } \\
\text { principals, } & 8 \\
\text { recruitment } & \\
\text { managers, } & 31 \text { adult } \\
\text { refugees }\end{array}$ & $\begin{array}{l}\text { Ethnographic/ } \\
\text { Qualitative }\end{array}$ & Interview \\
\hline Li \& Grineva & 2016 & Article & 6 refugee students & Qualitative & Interview \\
\hline Nwosu \& Barnes & 2014 & Article & 5 adult refugees & Qualitative & Interview \\
\hline Prior \& Niesz & 2013 & Report & $\begin{array}{ll}3 & \text { preschool } \\
\text { students } & \end{array}$ & Qualitative & Interview \\
\hline Roxas \& Roy & 2012 & Article & $\begin{array}{l}6 \text { high school } \\
\text { students }\end{array}$ & $\begin{array}{l}\text { Ethnographic/ } \\
\text { Qualitative }\end{array}$ & Interview \\
\hline Sheikh \& Anderson & 2018 & Article & Review & Descriptive & Review \\
\hline Şan \& Koçlu & 2018 & Article & 152 adult refugees & Quantitative & Interview \\
\hline Toker Gökçe \& Acar & 2018 & Article & $\begin{array}{l}4 \text { school principals } \\
\text { and } 6 \text { teachers }\end{array}$ & Qualitative & Interview \\
\hline Woolis & 2017 & Article & Model Suggestion & Descriptive & Suggestions \\
\hline
\end{tabular}




\begin{tabular}{|c|c|c|c|c|c|}
\hline Yemini & 2017 & Article & Review & Descriptive & Review \\
\hline Yüksek & 2018 & Article & 24 refugee students & Quantitative & Application \\
\hline $\begin{array}{l}\text { Marshall, Butler, } \\
\text { Roche, Cumming, \& } \\
\text { Taknint }\end{array}$ & 2016 & Article & Review & Descriptive & Review \\
\hline
\end{tabular}

As it is stated at Table 2, there are 21 studies defined as interviews, 12 studies indicated as review, three studies labeled as application, one descriptive study, one comparison and one suggestion study. The studies included in this study are conducted between 2011 and 2019. Furthermore, only one study is written in a report type. Other 40 studies are articles. In terms of their research design, there are 21 studies used qualitative research design and 3 of them conducted with ethnographic research design, ten studies used descriptive, 9 studies used quantitative and one study conducted by using mixed- research design.

\section{Refugee Adaptation}

The refugee adaptation theme includes studies that examine the refugee adaptation process from different perspectives, such as political and psychosocial issues. First of all, Hayes and Endale (2018) assert that language problems after the migration causes academic difficulties and cultural conflicts between local and refugee students. Personal factors, interpersonal factors, and environmental factors affect refugee children's personality development (Ndengeyingoma, Montigny \& Miron, 2014). These conflicts may affect refugee students' identity development, as well. As a result of these conflicts, Syrian refugee children in Turkey may have experiences that impact their psychosocial adaptation, academic and social performance negatively (Çeri, Nasıroğlu, Ceri \& Çetin, 2018). Therefore, learning the language and the cultural codes of the host countries pave the way for the adaptation of refugee students and increase their academic success (Pastoor, 2017).

Some of the studies reveal that the interventions intended to promote refugee children's psychosocial adaptation should provide family involvement besides basic security and social support factors (Horlings \& Hein, 2018; Kok, Lee \& Low, 2017). Therefore, psychosocial adaptation programs inside schools should involve parents and inform them about the psychosocial adaptation process, as well. Social support received from families, teachers, 
friends, and other communication networks has a crucial role in the psychosocial adaptation of refugee adolescents (Kok et al. 2017) and has a positive effect on refugee students' psychosocial adaptation (Özcan, 2019). Hence, while handling stressful life events, refugee students should get support from their families, peers, and teachers as well.

Prejudices of teachers who are working with refugee students prevent them from contributing cultural diversity and meeting refugee students' educational needs (Kovinthan, 2016). Teachers' judgments about refugees and their biases may influence the classroom environment as well. Thus, while working with refugee students, the systems that may affect them should be considered, and the culturally sensitive intervention programs should be developed (Stewart, 2012).

\section{School Experiences}

School experiences theme emerged from the study about the experiences of school components that are working with refugee students. As a result of this study, Mola Okoko (2011) states that school principals should create an environment where all of the school components (teachers, students, and families) can share responsibilities in any situation and spread their culture. Accordingly, refugee students may start to feel that they belong to the school and the city as well.

Tanaka (2013) indicates that preschool education has a positive effect, especially for children who live in refugee camps to interact with their peers, realize their positive feelings, and promote their psychosocial development. Consequently, preschool education paves the way for a better psychosocial adaptation of refugee students during their educational process. As it is indicated above, refugee students' school experience plays a vital role in the learning process and adaptation to the host country (Çelik \& İçduygu, 2018; Sheikh \& Anderson, 2018). Schools meet the need for refugee students to belong, helping them to adapt and feel safe in the first days of migration (Hastings, 2012; Prior \& Niesz, 2013). According to Doğutaş (2016), refugees who learn Turkish, begin to communicate with their peers and feel that they belong to the host country. 
Furthermore, adult refugees who go to language courses have difficulties in adapting and finding jobs since they miss employment opportunities (Koyama, 2013). On the other hand, learning a new language, adapting to a new culture, and having high expectations by their communities put pressure on refugee children (Harris \& Marlowe, 2011; Yüksek, 2018). Considering children become the socializing agent inside their society because of their language proficiency, children start to be the ones who provide communication with the people from the host country.

Educational policies and cultural differences affect the relationship of refugee students with their local peers as well (Li \& Grineva, 2016). Consequently, multicultural education and training programs facilitate the academic adaptation of refugees (Nwosu \& Barnes, 2014; Toker Gökçe \& Acar, 2018). As Dündar (2019) stated, physical education courses are instrumental in the adaptation process of school-age Syrian students. Thus, it can be said that courses and programs that do not require language proficiency may help both refugees and local students to get to know each other.

\section{Policies}

Theme named policies indicate the effect of different policies on refugees' psychosocial adaptation process. First of all, cultural and language differences that refugee students and families encounter prevent them from expressing their educational needs (Brenner \& KiaKeating, 2016; Busch, Bihler, Lembcke, Buchmüller, Diers \& Leyendecker, 2018). The different cultural backgrounds of refugee students may lead to conflicts inside the school, and because of this issue, refugee students may be exposed to peer bullying (Nakeyar, Esses \& Reid, 2018).

Therefore, schools need systematic and sufficient psychosocial programs that support and represent refugee children inside the school (de Wal Pastoor, 2015). Refugee families and professionals, including teachers who are working with refugees, need the training to facilitate refugees' psychosocial adaptation. Furthermore, refugee students' access to educational and health services should be promoted (Fegert, Diehl, Leyendecker, Hahlweg \& Prayon-Blum, 2018; de Wal Pastoor, 2015). These pieces of training should be systematic and cover refugee students' needs inside the school. 
Obtaining parents' support during the educational process and determining the clear and satisfiable boundaries empower teachers' beliefs on their self- sufficiency (Busch et al., 2018). Thus, every component of the school, including parents, teachers, principals, and students should be educated during the psychosocial adaptation process inside the schools. When refugee students have access to education and their fathers are working, they have a good life quality (Siah, Lee \& Goh, 2015). Family components are vital and need training as well to help refugee students access education.

In the context of refugees, higher education facilitates refugees' psychosocial adaptation as well as support their access to education (Crea, 2016). Accordingly, higher education institutes should be considered as well in the case of psychosocial adaptation during the educational process. Higher education facilities such as social clubs, gyms, and libraries help refugee students to adapt to their new environment and socialize with their peers.

Policies theme covers the policies about refugee students' adaptation process to their new social environment. School and educational policies have a notable impact on the education of refugees undoubtedly (Alpaydın, 2017). On the other hand, policies about the economic independence of refugee people influence education as well. As a result of the limited financial assistance granted by the host country, refugee students have difficulties in continuing to school. Therefore, they prefer to work to support their families (Roxas \& Roy, 2012). Consequently, many refugee students may need to work rather than going to school and getting an education.

The policies of the host countries on the language learning and adaptation of refugees affect the refugees' employment status (Campion, 2018; Şan \& Koçlu, 2018; Yemini, 2017). Refugees should improve their language proficiency in the host country to find a job and sustain their life in a new environment. Financial assistance for refugee people may be inadequate after a while. Thus, during the adaptation process, refugees' employment skills, as well as language skills, should be developed and supported by sustainable policies (Koyama, 2015; Woolis, 2017). In the adaptation process, refugees need to recognize their identity (Fruja Amthor, 2017) and find a job to sustain their life. 


\section{Refugee Health}

Refugees' health is the fourth theme, which indicates the adaptation process related to refugees' physiological and psychological health. Considering the difficulties, they experienced before, during and after immigration, it is not surprising that the refugee group has problems in terms of mental health; it is stated that refugees show compliance, perseverance and psychological flexibility against these difficulties (Marshall, Butler, Roche, Cumming, \& Taknint, 2016). The stress levels and behaviors of primary caregivers during the relocation process affect the mental health of adolescents and children (Betancourt, Yudron, Wheaton, W., \& Smith-Fawzi, 2012). However, there are some protective factors for refugee people to avoid unhealthful effects of the migration process. The vital protective factor is religious motifs that help refugees feel emotionally well (Keri \& Sleiman, 2017).

\section{Discussion and Conclusion}

This meta-analysis study aims to review articles that include examples of good practice for school counselors and teachers working with refugee students. Within this aim, a total of 41 studies were included in this review. Among 41 of these studies, 18 of them covered the psychosocial adjustment of the refugee students in the education process, and 23 of them explained the general adjustment process of the refugee students in the education process. In this meta-analysis study, 40 studies were presented in the article format, and one research was written in the report format. Based on the results obtained in the light of literature, under this section, practical recommendations for school counselors and teachers working with refugee students are provided.

This study aims to analyze the studies related to the refugees' adaptation process inside their educational process. Therefore, it is aimed to present good practices for teachers and school counselors who are working at refugee- receiving schools. In light of analyzing these 41 studies about the refugees' adaptation process, holistic adaptation programs for refugee students may be developed. These 41 studies divided into four main themes; refugees' adaptation, school experiences, policies, and refugee health. 
The first theme represented refugees' adaptation, comparison studies explained the refugees' adaptation process from different dimensions. Refugees' adaptation process has an influence on their biological and psychological health besides their educational needs. Furthermore, this adaptation process also affects local students and families as well. Therefore, they should be considered during the adaptation process of refugee students.

The theme named school experiences represent the fact that school experiences of refugee students have an indispensable impact on their learning process and their adaptation to the host country. Schools provide language proficiency and the customs of society. Moreover, refugee students may start to feel belonging to their host country via school experiences. Students who learn the language and attain the activities that do not require language proficiency start to develop healthier relationships with their local peers and teachers. It can be said that schools are the places where refugee students commence their adaptation process.

Policies theme demonstrate the fact that the policies of the host country are also a significant dimension for the adaptation process of refugees. Employment and language policies of the host country are the most indicative ones of the adaptation process. Furthermore, cultural and language proficiency differences are mentioned in these studies. The last theme, called refugee health, represents the studies about refugees' physiological and psychological health.

As it is indicated, the studies included schools that need more integrated and holistic programs for the adaptation of refugee students. These holistic programs should consider every component of the school, such as local students and families, teachers, administration, and the institutions related to the schools such as NGOs and MoNE. These holistic school programs help to create a whole school response to the refugee adaptation process (Peterson et al., 2017). Schools are the places where refugee students face with both discrimination and belonging. On the other hand, holistic school programs can help refugee children to reduce prejudice and increase the belonging to their new environment (Gibson \& Rojas, 2006). As Pinson and Arnot (2010) stated in their study, the adaptation of refugee students is not just an educational issue. Practitioners who are working with refugee students should holistically consider the matter. As a result of the studies included in this meta-synthesis, there are some recommendations for school counselors and teachers who are working with refugee students to assist in creating holistic school programs. 


\section{Suggestions}

\section{Recommendations for School Counselors}

School counselors are particularly significant in the adaptation process of refugee students to school. The school counselors are familiar with all the components of the school, especially with local and refugee families, students, administrators, and other employees. School counselors are, therefore, fundamental for ensuring communication between school stakeholders during the adaptation of local and refugee students. Recommendations for school counselors working with refugee students are given in this section.

First of all, school counselors should first recognize the culture of refugee students. There may be differences between the educational experience that the students are accustomed to and the education and teacher behaviors delivered in the host country. Therefore, school counselors should first learn about the culture, education system, and teacher behaviors of refugee students in their country of origin and share the differences and similarities with the teachers working with refugee students.

School counselors should consider the migration paths of the refugee children as well. The migration routes used by refugee students and their families on their way to the host country can give information to the school counselors about the psychological condition of the students and their families. Information such as whether the student arrives in our country by plane or car, how they crossed the border and how they reached the border, may inform school counselors about the challenging life events encountered by the refugee student. Consequently, learning about the migration paths used by refugee students or their families will help the school counselors to understand the conditions that refugee students or their families are trying to cope with.

It should not be forgotten that the stressful life events experienced by refugee students are unique and unusual. For this reason, school counselors should obtain information about the economic status, family condition, losses with whom the refugee student came to the host country (mother, father, relative, or neighbor) and education backgrounds of refugee students in addition to the migration path used. Furthermore, it is usual for refugee students to have 
difficulties in communicating and providing the required information to school counselors while they try to reach them. It should be kept in mind that for refugee students, trust and supportive relationships emerge as primary needs before discipline and education. Refugee students who have been subjected to severe life events should be given time to express themselves.

Since there are unexpected compelling life events, they are exposed to, and refugee students may show signs of trauma and exhibit inappropriate behaviors in the classroom. The existing behavioral structure of the school and classroom may change, and therefore, the parents and teachers may consult the school counselor with negative feedback. To prevent these situations, school counselors should inform local students, teachers, and parents about the cultures, traumas, and losses of refugee students and should involve refugee students in the activities they organize. Activities such as anger control, emotion expression, empathy skills, orientation, and intercultural dialogue can be conducted, including refugee and local students. In this challenging adaptation process, school counselors should inform all stakeholders of the school and involve them in the adaptation process.

In addition to all these, many refugee students learn the host country's language before their parents and act as mediators between the family and the school. At the same time, refugee students adapt to their new environment earlier than their families. In many cases, refugee families have difficulties in adapting to the host country and may show signs of depression and anxiety. Therefore, school counselors should provide the support that can help refugee students balancing their responsibilities in school and family (Stewart, 2011).

\section{Recommendations for Teachers}

Refugee students encounter numerous psychosocial difficulties in which teachers feel inadequate in classroom management. It is known that teachers can play a crucial role in supporting the education process of refugee students. Teachers need to pay attention to the psychosocial well-being and academic development of refugee students to facilitate the adaptation of refugee students. Refugee students may have psychosocial problems that require follow-up by their teachers. An increase in the number of refugee students in the education system also requires teachers to play a supportive role in the students' mental health. In other 
words, that change in teachers' roles requires teachers to monitor the mental health of refugee students and to refer refugee students to receive professional support. Teachers have the competencies to help refugee students improve their psychosocial adjustment and thus protect their mental health.

Hamilton and Moore (2004) offered recommendations for teachers with refugee students in their classes. First of all, teachers should keep in mind that refugee students may show trauma, loss, and mourning reactions in the classroom. Teachers should approach sensitive and delicate to these reactions. In addition to this, it can sometimes be challenging to determine whether refugee students need additional support. Teachers should participate in appropriate training where they can learn about the reactions of refugee students against challenging life events and, thus, gain insight into how these reactions can be observed in the classroom. Those training can also be provided by psychological counselors in the form of seminars or information meetings.

Increasing the adaptation of refugee students to schools requires both additional resources and support of teachers' knowledge and expertise in this field. Creating support groups can help teachers to develop an understanding of working with refugee students, and also, they can find the opportunity to share their concerns about working with refugee students. Furthermore, he highest priority of refugee students is to feel safe. Frequently used practices to help refugee students feel safe at school and in the classroom include the implementation of activities and projects that promote small-group activities and intercultural dialogue. Small group activities help students to learn from each other while also helping to create a supportive environment for students. Intercultural activities and projects in which refugee students can share their traditional dances, songs, stories, or food will help refugee students feel important and valuable as they improve understanding, acceptance, and mutual respect throughout the school.

Communication with refugee students and their parents will also help to support students' adaptation to educational processes and mental health, reducing their sense of exclusion and paving the way for them to succeed. One of the problems that teachers frequently face in the education of refugee students is the difficulties they face when teaching the host country's language as a second language. Given the stressful life events that refugee students have experienced during and after their migration to the host country, it is clear that refugee students 
are not involved in the educational process with optimal effort. In other words, the school readiness for learning may not be at the desired level because of the adverse life events that refugee students are exposed to before they settle in a new country. Given these barriers to refugee students' learning a second language, it is essential to consider good practice examples that will make it easier for schools to teach the host country's language as a second foreign language to refugee students.

\section{Limitations and Suggestions for Future Research}

There are several limitations associated with this study. Studies included in this meta-synthesis use different indicators to measure the well-being and adaptation of refugee children who continue their education. Although there are some similarities among the measures that were used for the adaptation of refugee children, the effect of subjective measures are ignored. Future studies can focus on both objective educational outcomes (such as the academic success of refugee children) and subjective educational outcomes (such as how refugee children are treated at home and at school, how refugee children perceive their educational experiences?) to provide a complete picture of the issue. Children's own experiences of education and the contribution of education to their adaptation process should be investigated. Additionally, while exploring the role of education in the adaptation process of refugee students, the role of the school principals, teachers, and students' families should not be forgotten. Therefore, future research should explore the thoughts of these actors.

Besides, studies included in this study were of above moderate quality. In an attempt to include the studies that meet this study's criterias, all of the studies were published in peer-reviewed journals. Therefore, the themes identified in this article are limited by articles that are eligible to this study (Sandelowski, Docherty, \& Emden, 1997). Another limitation is that each study does not contribute equally to each theme. Therefore, the results and recommendations of this study may only reflect the researchers' perspective. Yet the triangulation method was used to minimize this effect. Each researcher read carefully the data and the emerged themes were highly salient and grounded in the data. 


\section{Statements of Ethics and Conflict of Interest}

"I, as the Corresponding Author, declare and undertake that in the study titled as "Educational Journey of Refugee Students: Suggestions for Practitioners", scientific, ethical and citation rules were followed; Turkish Online Journal of Qualitative Inquiry Journal Editorial Board has no responsibility for all ethical violations to be encountered, that all responsibility belongs to the author/s and that this study has not been sent to any other academic publication platform for evaluation."

\section{References}

Acartürk, C., McGrath, M., Roberts, B., İlkkursun, Z., Cujpers, P., Sijbrandij, M. Sandorp, E., Ventevogel, P., Mckee, M. \& Fuhr, D. C. (2020). Prevalence and predictors of common mental disorders among Syrian refugees in Istanbul, Turkey: a crosssectional study. Social Psychiatry and Psychiatric Epidemiology, https://doi.org/10.1007/s00127-020-01941-6

Alpaydın, Y. (2017). An analysis of educational policies for school-aged Syrian refugees in Turkey. Journal of Education and Training Studies, 5(9), 36-44.

Balkar, B., Şahin, S., \& Işıklı Babahan, N. (2016). Problems confronted by Syrian teachers working at temporary education centers (TECs). Journal of Theory and Practice in Education, 12(6), 1290-1310.

Barbara, J. (2006). Impact of war on children and imperative to end war. Medicine and Peace, 47, 891- 894.

Barry, C.A., Britten, N., Barber, C. \& Stevenson, F. (1999). Using reflexivity to optimize teamwork in qualitative research. Qualitative Health Research, 9(1), 26-44, doi: $10.1177 / 104973299129121677$

Betancourt, T. S., Yudron, M., Wheaton, W., \& Smith-Fawzi, M. C. (2012). Caregiver and adolescent mental health in Ethiopian Kunama refugees participating in an emergency education program. Journal of Adolescent Health, 51(4), 357-365.

Brenner, M. E., \& Kia-Keating, M. (2016). Psychosocial and academic adjustment among resettled refugee youth. In Annual Review of Comparative and International Education 2016 (pp. 221-249). Emerald Group Publishing Limited. 
Busch, J., Bihler, L. M., Lembcke, H., Buchmüller, T., Diers, K., \& Leyendecker, B. (2018). Challenges and solutions perceived by educators in an early childcare program for refugee children. Frontiers in psychology, 9, 1-10, https://doi.org/10.3389/fpsyg.2018.01621

Campion, E. D. (2018). The career adaptive refugee: Exploring the structural and personal barriers to refugee resettlement. Journal of Vocational Behavior, 105, 6-16.

Canterbury Christ Church University. Canterbury Christ Church University and refugee students: From hostile to holistic models. International Journal of Inclusive Education, 14(3), 247-267. doi:10.1080/13603110802504523

Crea, T. M. (2016). Refugee higher education: Contextual challenges and implications for program design, delivery, and accompaniment. International Journal of Educational Development, 46, 12-22.

Çelik, Ç., \& İçduygu, A. (2018). Schools and refugee children: the case of Syrians in Turkey. International Migration, 57(2), 253-267.

Çeri, V., Nasıroğlu, S., Ceri, M., \& Çetin, F. Ç. (2018). Psychiatric morbidity among a school sample of Syrian refugee children in Turkey: A cross-sectional, semistructured, standardized interview-based study. Journal of the American Academy of Child and Adolescent Psychiatry, 57(9), 696-698.

de Wal Pastoor, L. (2015). The mediational role of schools in supporting psychosocial transitions among unaccompanied young refugees upon resettlement in Norway. International Journal of Educational Development, 41, 245-254

Dogutas, A. (2016). Tackling with refugee children's problems in Turkish schools. Journal of Education and Training Studies, 4(8), 1-8.

Dorman, S. (2014). Educational needs assessment for urban Syrian refugees in Turkey (Rep.). İstanbul: YUVA Association.

Dryden-Peterson, S. (2014). Refugee education in countries of the first asylum: Breaking open the black box of pre-resettlement experiences. Theory and Research in Education, 14(2), 131-148. doi:10.1177/1477878515622703

Dündar, A. (2019). Impact of physical education lesson on adaptation of Syrian refugee school age children in Turkey. World Journal of Education, 9(1), 266-273.

Ereş, F. (2016). Problems of the immigrant students' teachers: Are they ready to teach?.International Education Studies, 9(7), 64-71. 
Fegert, J. M., Diehl, C., Leyendecker, B., Hahlweg, K., \& Prayon-Blum, V. (2018). Psychosocial problems in traumatized refugee families: overview of risks and some recommendations for support services. Child and adolescent psychiatry and mental health, 12(1), 5 .

Fruja Amthor, R. (2017). "If only I did not have that label attached to me": Foregrounding selfpositioning and intersectionality in the experiences of immigrant and refugee youth. Multicultural Perspectives, 19(4), 193-206.

Hamilton, R. J., \& Moore, D. (Eds.). (2004). Educational interventions for refugee children: Theoretical perspectives and implementing best practice. Psychology Press.

Harris, V., \& Marlowe, J. (2011). Hard yards high hopes: The educational challenges of African refugee university students in Australia. International Journal of Teaching, Learning and Higher Education 23(2),186-196.

Hastings, C. (2012). The experience of male adolescent refugees during their transfer and adaptation to a UK secondary school. Educational Psychology in Practice, 28(4), 335351.

Hayes, S. W., \& Endale, E. (2018). “Sometimes my mind, it has to analyze two things”: Identity development and adaptation for refugee and newcomer adolescents. Peace and Conflict: Journal of Peace Psychology, 24(3), 283.

Horlings, A., \& Hein, I. (2018). Psychiatric screening and interventions for minor refugees in Europe: an overview of approaches and tools. European journal of pediatrics, 177(2), 163-169.

Gardner, H. (1995). "Multiple Intelligences" as a Catalyst. National Council of Teachers of English, 84(8), 16-18.

İstanbul Bilgi Üniversitesi Çocuk Çalışmaları Birimi (İstanbul Bilgi University Child Studies Unit) (2015). Suriyeli mülteci çocukların Türkiye devlet okullarındaki durumu: Politika ve uygulama önerileri.

Kaya, A., \& Kıraç, A. (2016). Vulnerability assessment of Syrian refugees in İstanbul (Rep.). İstanbul: Suporttolife.

Kéri, S., \& Sleiman, C. (2017). Religious conversion to Christianity in Muslim refugees in Europe. Archive for the Psychology of Religion, 39(3), 283-294.

Kok, J. K., Lee, M. N., \& Low, S. K. (2017). Coping abilities and social support of Myanmar teenage refugees in Malaysia. Vulnerable Children and Youth Studies, 12(1), 71-80. 
Kovinthan, T. (2016). Learning and teaching with loss: Meeting the needs of refugee children through narrative inquiry. Diaspora, indigenous, and minority education, 10(3), 141155.

Koyama, J. (2013). Resettling notions of social mobility: locating refugees as 'educable' and 'employable'. British Journal of Sociology of education, 34(5-6), 947-965.

Koyama, J. (2015). Learning English, working hard, and challenging risk discourses. Policy Futures in Education, 13(5), 608-620.

Lachal, J., Revah- Levy, A., Orri, M., \& Moro, M. (2017). Metasynthesis: An original method to synthesize Qualitative Literature in Psychiatry. Frontiers in Psychiatry, 8(269). doi:10.3389/fpsyt.2017.00269

Li, X., \& Grineva, M. (2016). Academic and social adjustment of high school refugee youth in Newfoundland. TESL Canada Journal, 34(1), 51-71.

Marshall, E. A., Butler, K., Roche, T., Cumming, J., \& Taknint, J. T. (2016). Refugee youth: A review of mental health counselling issues and practices. Canadian Psychology/Psychologie canadienne, 57(4), 308-319.

Mercan Uzun, E., \& Bütün, E. (2016). Okul Oöncesi eğitim kurumlarındaki Suriyeli sığınmacı Cçocukların karşılaştıkları sorunlar hakkında Oöğretmen görüşleri [Teachers' Views Regarding the Problems Encountered by Syrian Refugee Children in Preschool Education Institutions]. Uluslararası Erken Çocukluk Eğitimi Çalışmaları Dergisi, 1(1), 72-83.

Mola Okoko, J. (2011). Experiences of school principals with newcomers from war-affected countries in Africa. Diaspora, Indigenous, and Minority Education, 5(4), 222-234.

Nakeyar, C., Esses, V., \& Reid, G. J. (2018). The psychosocial needs of refugee children and youth and best practices for filling these needs: A systematic review. Clinical child psychology and psychiatry, 23(2), 186-208.

Ndengeyingoma, A., Montigny, F. D., \& Miron, J. M. (2014). Development of personal identity among refugee adolescents: Facilitating elements and obstacles. Journal of child health care, 18(4), 369-377.

Nwosu, O. C., \& Barnes, S. L. (2014). Where 'difference is the norm': Exploring refugee student ethnic identity development, acculturation, and agency at Shaw academy. Journal of Refugee Studies, 27(3), 434-456. 
Özcan, Z. (2019). Göçün travmatik etkilerini azaltmada sosyal desteğin rolü üzerine deneysel bir Araştırma [An experimental research on the role of social support in reducing the traumatic effects of migration]. Bilimname, 37(1), 1001-1028.

Özel, D. (2018). Examining needs and issues of refugee-receiving schools in Turkey from the perspectives of school counselors (Unpublished master's thesis). Ankara, Middle East Technical University.

Özer, Y., Komsuoğlu, A., \& Ateşok, Z. (2016). Türkiye'deki suriyeli çocukların eğitimi: Sorunlar ve Cçözüm Oönerileri (Education of Syrian Children in Turkey: Problems and Suggestions). The Journal of Academic Social Science, 4(37), 34- 42.

Pastoor, L. D. W. (2017). Reconceptualising refugee education: exploring the diverse learning contexts of unaccompanied young refugees upon resettlement. Intercultural Education, 28(2), 143-164.

Peterson, A., Meehan, C., Ali, Z. \& Durrant, I. (2017) What are the educational needs and experiences of asylum-seeking and refugee children, including those who are unaccompanied, with a particular focus on inclusion? - A literature review.

Prior, M. A., \& Niesz, T. (2013). Refugee children's adaptation to American early childhood classrooms: A narrative inquiry. The Qualitative Report, 18(20), 1-17.

Roxas, K., \& Roy, L. (2012). “That's how we roll”: A case study of a recently arrived refugee student in an urban high school. The Urban Review, 44(4), 468-486.

Sakız, H. (2016). Göçmen çocuklar ve okul kültürleri: Bir bütünleşme Oönerisi [Immigrant children and their school culture: an integration proposal]. Göç Dergisi, 3(1), 65-81.

Sahin, C., Dagli, T. E., Acarturk, C. \& Sahin Dagli, F. (2020). Vulnerabilities of Syrian refugee children in Turkey and actions taken for prevention and management in terms of health and wellbeing. Child Abuse and Neglect, doi: 10.1016/j.chiabu.2020.104628

Saldana, J. (2013). Power and conformity in today's schools. International Journal of Humanities and Social Science, 3(1), 228-232.

Sandelowski, M., Docherty, S. \& Emden, C. (1997) Qualitative metasynthesis: issues and techniques. Research in Nursing and Health, 20, 365-371.

Sarmini, I., Topcu, E. \& Scharbodt, O. (2020). Integrating Syrian refugee in Turkey: The role of Turkish language skills (a case study in Gaziantep). International Journal of Educational Research Open, https://doi.org/10.1016/j.ijedro.2020.100007 
Sheikh, M., \& Anderson, J. R. (2018). Acculturation patterns and education of refugees and asylum seekers: A systematic literature review. Learning and Individual Differences, $67,22-32$.

Siah, P. C., Lee, W. Y., \& Goh, L. Y. (2015). Quality of life among refugee children in Malaysia-a brief report. Vulnerable Children and Youth Studies, 10(4), 294-299.

Stewart, J. (2011). Supporting refugee children: Strategies for eucators. University of Toronto Press.

Stewart, J. (2012). Transforming schools and strengthening leadership to support the educational and psychosocial needs of war-affected children living in Canada. Diaspora, Indigenous, and Minority Education, 6(3), 172-189.

Şan, F., \& Koçlu, S. (2018). Determination of communication problems of the refugees in Sakarya and the need for community interpreting. International Journal of Language Academy, 6(4), 1-16.

Şeker, B., \& Sirkeci, İ. (2015). Challenges for refugee children at school in eastern Turkey. Economics and Sociology, 8(4), 122- 133.

Tanaka, A. (2013). Assessment of the psychosocial development of children attending nursery schools in Karen refugee camps in Thailand. International Journal of Early Childhood, 45(3), 279-305.

Toker Gokce, A., \& Acar, E. (2018). School principals' and teachers' problems related to the education of refugee students in Turkey. European Journal of Educational Research, $7(3), 473-484$.

Tong, A., Flemming, K., McInnes, E., Oliver, S., \& Craig, J. (2012). Enhancing transparency in reporting the synthesis of qualitative research: ENTREQ. BMC Medical Research Methodology, 12(181). doi:10.1186/1471-2288-12-181.

United Nations High Commissioner for Refugees UNHCR. (2014). 2014 Syria regional response plan Turkey.

Woolis, D. D. (2017). Communities that produce value and foster sustainable learning: the case of action for refugee educators. Knowledge Management for Development Journal, 13(3), 39-59.

Yemini, M. (2017). Internationalization in conflict-ridden societies and within refugee populations. European Education, 49(4), 205-209. 
Yüksek, C. (2018). Dealing with stress using social theatre techniques with young Syrian students adapting to a new educational system in Turkey: a case study. Intervention (15718883), 16(2), 175-180.

\section{Appendix 1}

\section{Studies Included in the Meta-Analysis of Psychosocial Adaptation of Refugee Students in the Education Process}

Brenner, M. E., \& Kia-Keating, M. (2016). Psychosocial and academic adjustment among resettled refugee youth. In Annual Review of Comparative and International Education 2016 (pp. 221-249). Emerald Group Publishing Limited.

Busch, J., Bihler, L. M., Lembcke, H., Buchmüller, T., Diers, K., \& Leyendecker, B. (2018). Challenges and solutions perceived by educators in an early childcare program for refugee children. Frontiers in psychology, 9.

Crea, T. M. (2016). Refugee higher education: Contextual challenges and implications for program design, delivery, and accompaniment. International Journal of Educational Development, 46, 12-22.

Çeri, V., Nasıroğlu, S., Ceri, M., \& Çetin, F. Ç. (2018). Psychiatric morbidity among a school sample of Syrian refugee children in Turkey: A cross-sectional, semistructured, standardized interview-based study. Journal of the American Academy of Child and Adolescent Psychiatry, 57(9), 696-698.

de Wal Pastoor, L. (2015). The mediational role of schools in supporting psychosocial transitions among unaccompanied young refugees upon resettlement in Norway. International Journal of Educational Development, 41, 245-254.

Fegert, J. M., Diehl, C., Leyendecker, B., Hahlweg, K., \& Prayon-Blum, V. (2018). Psychosocial problems in traumatized refugee families: overview of risks and some recommendations for support services. Child and adolescent psychiatry and mental health, 12(1), 5 .

Hayes, S. W., \& Endale, E. (2018). “Sometimes my mind, it has to analyze two things”: Identity development and adaptation for refugee and newcomer adolescents. Peace and Conflict: Journal of Peace Psychology, 24(3), 283. 
Horlings, A., \& Hein, I. (2018). Psychiatric screening and interventions for minor refugees in Europe: an overview of approaches and tools. European journal of pediatrics, 177(2), 163-169.

Kok, J. K., Lee, M. N., \& Low, S. K. (2017). Coping abilities and social support of Myanmar teenage refugees in Malaysia. Vulnerable Children and Youth Studies, 12(1), 71-80.

Kovinthan, T. (2016). Learning and teaching with loss: Meeting the needs of refugee children through narrative inquiry. Diaspora, indigenous, and minority education, 10(3), 141155.

Mola Okoko, J. (2011). Experiences of school principals with newcomers from war-affected countries in Africa. Diaspora, Indigenous, and Minority Education, 5(4), 222-234.

Nakeyar, C., Esses, V., \& Reid, G. J. (2018). The psychosocial needs of refugee children and youth and best practices for filling these needs: A systematic review. Clinical child psychology and psychiatry, 23(2), 186-208.

Ndengeyingoma, A., Montigny, F. D., \& Miron, J. M. (2014). Development of personal identity among refugee adolescents: Facilitating elements and obstacles. Journal of child health care, 18(4), 369-377.

Özcan, Z. (2019). Göçün Travmatik Etkilerini Azaltmada Sosyal Desteğin Rolü Üzerine Deneysel Bir Araştırma [An experimental research on the role of social support in reducing the traumatic effects of migration]. Bilimname, 37(1), 1001-1028.

Pastoor, L. D. W. (2017). Reconceptualising refugee education: exploring the diverse learning contexts of unaccompanied young refugees upon resettlement. Intercultural Education, 28(2), 143-164.

Siah, P. C., Lee, W. Y., \& Goh, L. Y. (2015). Quality of life among refugee children in Malaysia-a brief report. Vulnerable Children and Youth Studies, 10(4), 294-299.

Stewart, J. (2012). Transforming schools and strengthening leadership to support the educational and psychosocial needs of war-affected children living in Canada. Diaspora, Indigenous, and Minority Education, 6(3), 172-189.

Tanaka, A. (2013). Assessment of the psychosocial development of children attending nursery schools in Karen refugee camps in Thailand. International Journal of Early Childhood, 45(3), 279-305. 


\section{Appendix 2}

\section{Studies Included in the Meta-Analysis of the Adaptation of Refugee Students in the}

\section{Education Process}

Alpaydın, Y. (2017). An analysis of educational policies for school-aged Syrian refugees in Turkey. Journal of Education and Training Studies, 5(9), 36-44.

Betancourt, T. S., Yudron, M., Wheaton, W., \& Smith-Fawzi, M. C. (2012). Caregiver and adolescent mental health in Ethiopian Kunama refugees participating in an emergency education program. Journal of Adolescent Health, 51(4), 357-365.

Campion, E. D. (2018). The career adaptive refugee: Exploring the structural and personal barriers to refugee resettlement. Journal of Vocational Behavior, 105, 6-16.

Çelik, Ç., \& İçduygu, A. (2018). Schools and refugee children: the case of Syrians in Turkey. International Migration, 57(2), 253-267.

Dogutas, A. (2016). Tackling with refugee children's problems in Turkish schools. Journal of Education and Training Studies, 4(8), 1-8.

Dundar, A. (2019). Impact of physical education lesson on adaptation of Syrian refugee school age children in Turkey. World Journal of Education, 9(1), 266-273.

Fruja Amthor, R. (2017). "If only I did not have that label attached to me": Foregrounding selfpositioning and intersectionality in the experiences of immigrant and refugee youth. Multicultural Perspectives, 19(4), 193-206.

Harris, V., \& Marlowe, J. (2011). Hard yards high hopes: The educational challenges of African refugee university students in Australia.

Hastings, C. (2012). The experience of male adolescent refugees during their transfer and adaptation to a UK secondary school. Educational Psychology in Practice, 28(4), 335351.

Kéri, S., \& Sleiman, C. (2017). Religious conversion to Christianity in Muslim refugees in Europe. Archive for the Psychology of Religion, 39(3), 283-294.

Koyama, J. (2013). Resettling notions of social mobility: locating refugees as 'educable' and 'employable'. British Journal of Sociology of education, 34(5-6), 947-965.

Koyama, J. (2015). Learning English, working hard, and challenging risk discourses. Policy Futures in Education, 13(5), 608-620.

Li, X., \& Grineva, M. (2016). Academic and social adjustment of high school refugee youth in Newfoundland. TESL Canada Journal, 34(1), 51-71. 
Marshall, E. A., Butler, K., Roche, T., Cumming, J., \& Taknint, J. T. (2016). Refugee youth: A review of mental health counselling issues and practices. Canadian Psychology/Psychologie canadienne, 57(4), 308.

Nwosu, O. C., \& Barnes, S. L. (2014). Where 'difference is the norm': Exploring refugee student ethnic identity development, acculturation, and agency at Shaw academy. Journal of Refugee Studies, 27(3), 434-456.

Prior, M. A., \& Niesz, T. (2013). Refugee children's adaptation to American early childhood classrooms: A narrative inquiry. The Qualitative Report, 18(20), 1-17.

Roxas, K., \& Roy, L. (2012). “That's how we roll”: A case study of a recently arrived refugee student in an urban high school. The Urban Review, 44(4), 468-486.

Sheikh, M., \& Anderson, J. R. (2018). Acculturation patterns and education of refugees and asylum seekers: A systematic literature review. Learning and Individual Differences, $67,22-32$.

Şan, F. \& Koçlu, S. (2018). Determination of communication problems of the refugees in Sakarya and the need for community interpreting. International Journal of Language Academy, 6(4), 1-16.

Toker Gokce, A., \& Acar, E. (2018). School principals' and teachers' problems related to the education of refugee students in Turkey. European Journal of Educational Research, $7(3), 473-484$.

Woolis, D. D. (2017). Communities that produce value and foster sustainable learning: the case of action for refugee educators. Knowledge Management for Development Journal, 13(3), 39-59.

Yemini, M. (2017). Internationalization in conflict-ridden societies and within refugee populations. European Education, 49(4), 205-209.

Yüksek, C. (2018). Dealing with stress using social theatre techniques with young Syrian students adapting to a new educational system in Turkey: a case study. Intervention (15718883), 16(2), 175-180. 